OPEN ACCESS

Edited by:

Joav Merrick

Health Services, Ministry of Social Affairs, Israel

Reviewed by: Kishore Alugupalli, Thomas Jefferson University, USA Philip E. Stewart, National Institutes of Health, USA Mazyanga Lucy Mazaba-Liwewe, World Health Organisation, Zambia

*Correspondence:

Michel Drancourt michel.drancourt@univ-amu.fr

Specialty section: This article was submitted to Infectious Diseases, a section of the journal Frontiers in Public Health

Received: 02 July 2015 Accepted: 29 October 2015 Published: 11 November 2015

Citation:

Fotso Fotso $A$ and Drancourt $M$ (2015) Laboratory Diagnosis of Tick-Borne African Relapsing Fevers: Latest Developments.

Front. Public Health 3:254. doi: 10.3389/fpubh.2015.00254

\section{Laboratory Diagnosis of Tick-Borne African Relapsing Fevers: Latest Developments}

\author{
Aurélien Fotso Fotso and Michel Drancourt* \\ Aix Marseille Université, URMITE, UMR 6236, CNRS 7278, IRD 198, INSERM 1095, IFR 48, Méditerranée Infection, Faculté \\ de Médecine, Marseille, France
}

In Africa, relapsing fevers caused by ectoparasite-borne Borrelia species are transmitted by ticks, with the exception of Borrelia recurrentis, which is a louse-borne spirochete. These tropical diseases are responsible for mild to deadly spirochetemia. Cultured Borrelia crocidurae, Borrelia duttonii, and Borrelia hispanica circulate alongside at least six species that have not yet been cultured in vectors. Direct diagnosis is hindered by the use of non-specific laboratory tools. Indeed, microscopic observation of Borrelia spirochaeta in smears of peripheral blood taken from febrile patients lacks sensitivity and specificity. Although best visualized using dark-field microscopy, the organisms can also be detected using Wright-Giemsa or acridine orange stains. PCR-based detection of specific sequences in total DNA extracted from a specimen can be used to discriminate different relapsing fever Borreliae. In our laboratory, we developed a multiplex realtime PCR assay for the specific detection of $B$. duttonii/recurrentis and B. crocidurae: multispacer sequence typing accurately identified cultured relapsing fever borreliae and revealed diversity among them. Other molecular typing techniques, such as multilocus sequence analysis of tick-borne relapsing fever borreliae, showed the potential risk of human infection in Africa. Recent efforts to culture and sequence relapsing fever borreliae have provided new information for reassessment of the diversity of these bacteria. Recently, matrix-assisted laser desorption/ionization time-of-flight mass spectrometry has been reported as a means of identifying cultured borreliae and of identifying both vectors and vectorized pathogens such as detecting relapsing fever borreliae directly in ticks. The lack of a rapid diagnosis test restricts the management of such diseases. We produced monoclonal antibodies against $B$. crocidurae in order to develop cheap assays for the rapid detection of relapsing fever borreliae. In this paper, we review point-of-care diagnosis and confirmatory methods.

Keywords: diagnosis, laboratory, relapsing fever borreliae, Africa, point-of-care

\section{INTRODUCTION}

In Africa, relapsing fever borreliae are neglected vector-borne pathogens responsible for various febrile presentations and are most commonly suspected in malaria-like symptoms (1). They are ectoparasite-borne infections that are transmitted by ticks, with the exception of Borrelia recurrentis, which is a louse-borne spirochete (1). As a result, this latter organism 
will not be considered in this review, which focuses on tickborne borreliae. Relapsing fevers are a concern for public health in local populations as well as for foreigners visiting endemic African countries. Currently, three cultured tick-borne species (Borrelia crocidurae, Borrelia duttonii, and Borrelia hispanica) (2) are in circulation, in addition to the as yet uncultured Borrelia merionesi in Ornithodoros ticks in Morocco (3), Candidatus Borrelia algerica in febrile patients in Algeria (4) and an unnamed new species in Ornithodoros porcinus ticks in Tanzania (5), in the blood of Spheniscus demersus penguins in South Africa (6), in Rhipicephalus evertsi ticks from Nigeria (7), and new Borrelia species distinct from the Lyme disease and recurrent fever groups detected in Amblyomma cohaerens in Ethiopia (8). B. hispanica is prevalent in the north, $B$. crocidurae in the west, and $B$. duttonii in the east of Africa $(1,2)$. However, several species of Borrelia may circulate in the same geographic region (3). All species are transmitted by the bite of Ornithodoros soft ticks $(9,10)$. Since relapsing fever borreliae can present with fever, they are often misdiagnosed as malaria (11). Moreover, relapsing fever borreliae may form part of mixed infections, further complicating the diagnosis (12). A relapse within days is the clinical hallmark of these infections, causing mild to deadly septicemia and miscarriage in people exposed to endemic regions (1). The clinical picture initially includes a fever over $39^{\circ} \mathrm{C}$ with chills and polyalgia; it may also include vomiting, abdominal pain, and diarrhea. Physical examination may find rash, splenomegaly, and hepatomegaly (2). All species may cause iritis, iridocyclitis, uveitis, and central nervous system infection. The mortality rate is estimated to be between 2 and 5\%, depending on the causative Borrelia species, the highest mortality rate being observed with $B$. recurrentis (1). The most recent epidemiological data indicate that 43.92 million people living in rural Africa in endemic countries and 19.17 million travelers are at risk of relapsing fever in west and north African countries (3). The incidence of tick-borne relapsing fever has been measured at $11 \%$ in rural Senegal (9). Due to its sudden onset, and because the first fever attack is the most dangerous, lengthy diagnostic procedures, including in vitro culturing and animal inoculation, cannot be considered for routine diagnosis. Currently, detection of relapsing fever borreliae in Africa relies upon the observation of spirochaeta in smears of peripheral blood; however, the high morphological similarity between species does not allow for identification at the species level. Molecular methods, detecting single nucleotide polymorphisms in the 16S rRNA and flaB genes, 16S-23S ribosomal RNA intergenic spacer (IGS), multispacer sequence typing (MST), multilocus sequence typing (MLST), and multiplex quantitative real-time PCR $(4,13,14)$, may not be routinely available in most endemic regions (15). Nevertheless, rapid diagnosis of relapsing fever is warranted, since these cases require specific treatment and prophylaxis in order to avoid contact with small rodents and their ticks (12). Relapsing fevers remain undiagnosed partly due to the lack of point-of-care (POS) diagnostic tools in endemic countries (15), resulting from the fastidious nature of the tools and the lack of attention from doctors and microbiologists toward febrile patients returning from endemic areas. Here, we review the tools that are currently available for the diagnosis of relapsing fever borreliae in hosts in Africa.

\section{RAPID DIAGNOSIS AT THE POINT-OF-CARE}

The gold-standard diagnosis for relapsing fever borreliae is direct microscopic visualization of borreliae in a Giemsa-stained thick blood smears $(12,16)$. Borreliae are best detected in blood obtained while a patient is febrile. During subsequent febrile episodes, the number of circulating spirochaeta decreases, making it harder to detect them on a peripheral blood smear (16). One study, using thick blood smears from febrile cases stained with Giemsa and observed in 200 oil immersion fields $(\times 1000)$ (equivalent to about $0.5 \mu \mathrm{L}$ blood), determined that during the febrile episode, the blood-borne inoculum was $10^{3}-10^{5}$ borreliae per $\mathrm{mL}$ $(9,16)$. This figure indicates that conventional microscopic examination of a blood drop yields only one Borrelia every 10 microscopic fields. Accordingly, microscopic examination of red blood cells for Plasmodium may easily overlook borreliae, which are free in the plasma (17) or sticking to blood cells (Figure 1). Direct detection either of motile spirochaeta by dark-field microscopy or staining of borreliae by fluorescent antibody methods in such tissues may be used $(18,19)$. The inability of dark-field microscopic analysis to detect spirochaeta in 100 field-collected ticks (16 infected ticks) compared with PCR (22 infected ticks) (20) illustrated the need for more sensitive tests. To provide simple, fast, cheap, and sensitive diagnoses using equipment that is available in small health centers, a method based on enrichment of bacteria by centrifugation and detection by Giemsa staining was developed, which is capable of detecting fewer than 10 spirochaeta per $\mathrm{mL}$ of blood $(12,21)$. PCR-based detection of specific sequences is the modern method for POC laboratory diagnosis (15). Total DNA is most often extracted from blood using a QIAamp DNA Micro kit according to the manufacturer's protocol (QIAGEN, Hilden, Germany) $(4,22)$. Because of the close genetic and genomic proximity of the relapsing fever borreliae, as illustrated by $16 \mathrm{~S}$ rRNA gene sequence variability $\leq 1 \%$, confirmed by $B$. duttonii and $B$. recurrentis genomics, indicating that the two organisms belonged to the same bacterial species (22-24), molecular tests may detect

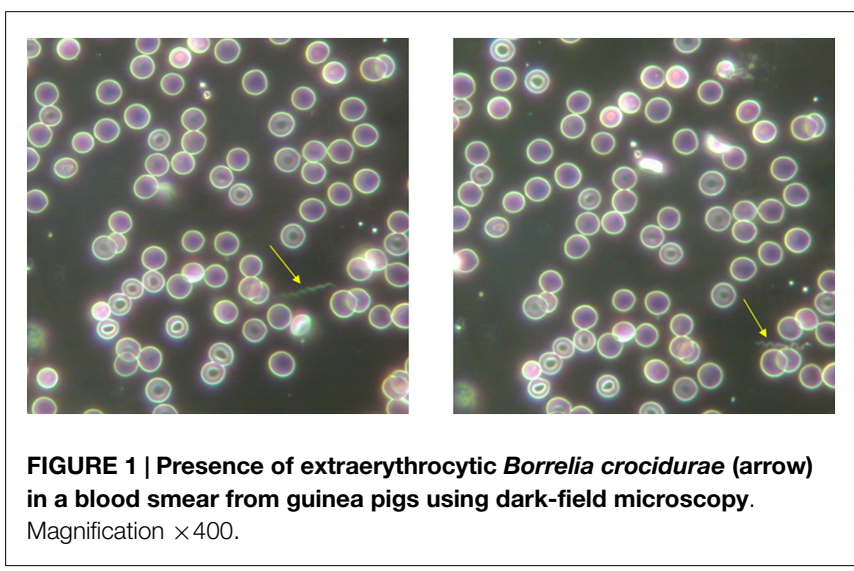




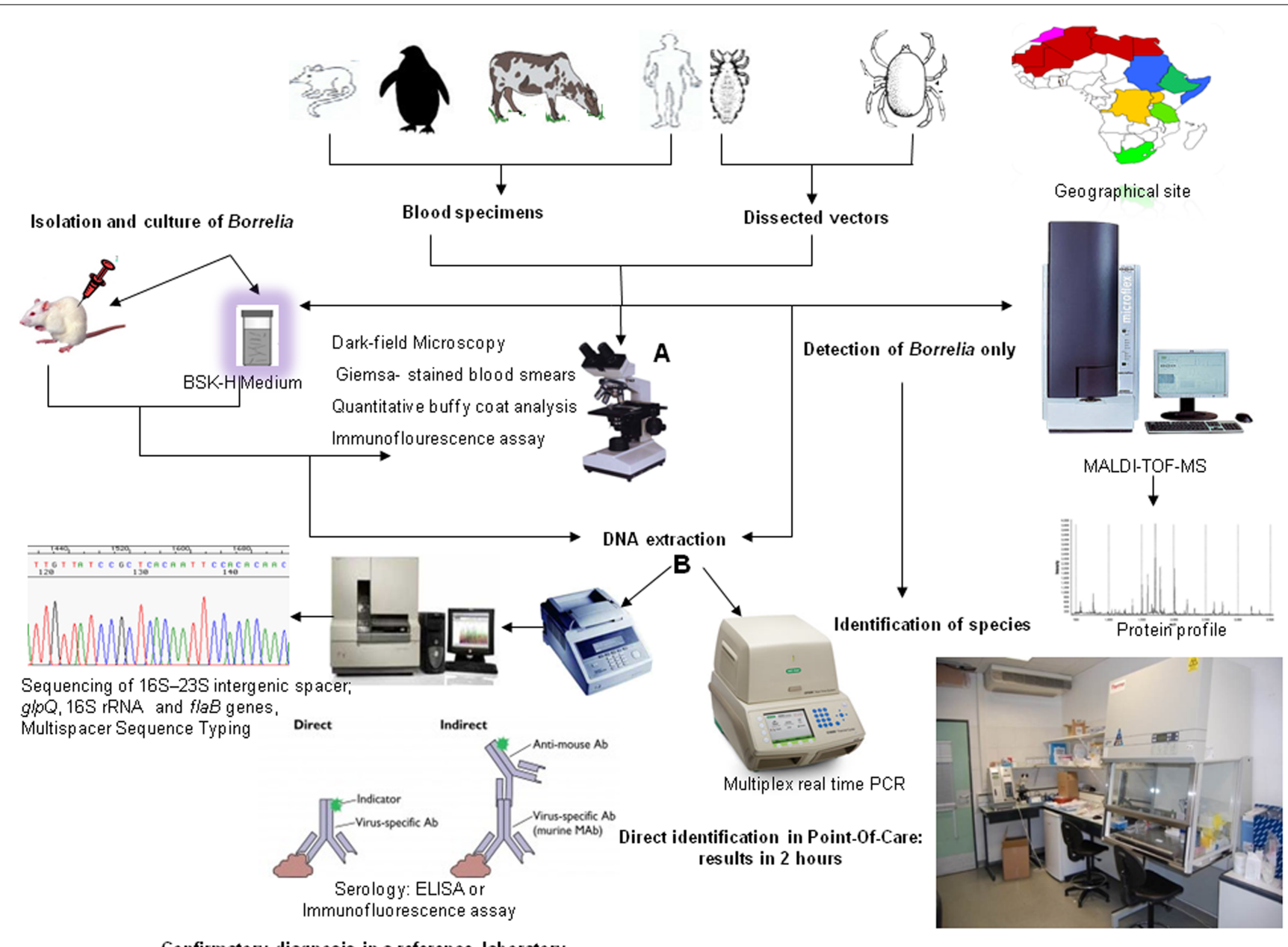

Confirmatory diagnosis in a reference laboratory

FIGURE 2 | Diagnosis of African relapsing fever: a review. Conventional microscopic identification (A) and molecular identification (B).

relapsing fever borreliae without providing species identification. Observations that the glycerophosphodiester phosphodiesterase $(g l p Q)$ gene and its antigenic protein product were present in relapsing fever borreliae and absent in Lyme disease borreliae led to the development of group-specific molecular and serological tests (25). Detection of Borrelia flagellin DNA (flaB) by real-time PCR amplification from the blood is highly sensitive and specific, detecting as few as 10 borreliae per $\mathrm{mL}$ of blood (26). Real-time PCR can be efficiently used in POC settings, as shown in rural Senegal $(15,27)$. In this example, extracted blood DNA could be stored at $4^{\circ} \mathrm{C}$ until used for PCR amplification. Ready-to-use lyophilized reagents can be prepared in a core-laboratory and shipped to rural POC facilities (15). The lyophilized mixtures can be stored for at least 2 months at $20^{\circ} \mathrm{C}$ without loss of activity (Figure 2). The same approach has recently been used for the POC molecular diagnosis of Buruli ulcers in order to facilitate the diagnosis of Mycobacterium ulcerans infection in endemic countries (27). While commercially available real-time PCR solutions may be beyond the financial capacities of some countries, specific financing programs are available to promote advanced molecular diagnosis in endemic countries, as illustrated by rural POC facilities (15).

\section{CONFIRMATORY DIAGNOSIS IN THE REFERENCE LABORATORY}

\section{Molecular Typing}

Molecular typing confirms Borrelia and allows for fine species identification. Several approaches, including analysis of the IGS located between the 16S rRNA and 23S rRNA genes, only explored the variability between $B$. duttonii and $B$. recurrentis (28). Moreover, IGS sequences overlapped between one $B$. duttonii phylogenetic group and one $B$. recurrentis group, with a second overlap being revealed upon subsequent analysis of further material (28). In Mali, the inclusion of MLST revealed the endemic foci of tickborne relapsing fever borreliae and the potential risk for human infection (14). Borrelia contains numerous linear and circular plasmids $(23,29,30)$. MLST looks for differences between plasmid profiles and DNA sequence data. MST looks for differences between five IGSs in $B$. crocidurae, $B$. duttonii, and $B$. recurrentis genomes. It is a suitable PCR-sequencing-based method for identifying and genotyping relapsing fever borreliae in Africa in both vectors and clinical specimens (13). B. hispanica is responsible for relapsing fever borreliae in Spain (31) and previous molecular 
TABLE 1 | Diagnosis of relapsing fever borreliae in travelers returning to Europe from Africa over the past 15 years.

\begin{tabular}{|c|c|c|c|}
\hline Reference laboratory & $\begin{array}{l}\text { Countries of } \\
\text { exposure }\end{array}$ & Methods & Reference \\
\hline $\begin{array}{l}\text { Infectious Diseases and Tropical Medicine ward in North Hospital, } \\
\text { Marseille, France }\end{array}$ & Senegal & $\begin{array}{l}\text { Microscopic } \\
\text { Molecular tests }\end{array}$ & (35) \\
\hline The Emergency Department of American Hospital of Paris, France & Mali & Microscopic & $(37)$ \\
\hline $\begin{array}{l}\text { Clinic and Laboratory of Infectious Diseases, University of Siena, } \\
\text { Siena, Italy }\end{array}$ & Senegal & $\begin{array}{l}\text { Microscopic } \\
\text { Molecular tests }\end{array}$ & $(36)$ \\
\hline Biology laboratory of the Centre Hospitalier d'Argenteuil, France & Senegal & $\begin{array}{l}\text { Microscopic } \\
\text { Molecular tests }\end{array}$ & $(38)$ \\
\hline $\begin{array}{l}\text { Service de Médecine Interne, Groupe Hospitalier Mutualiste de } \\
\text { Grenoble, France }\end{array}$ & & $\begin{array}{l}\text { Lyme disease serodiagnostic assays } \\
\text { (ELISA and Western blot) } \\
\text { Culture }\end{array}$ & \\
\hline University Hospital of Antwerp, Belgium & Senegal & Molecular tests & (39) \\
\hline \multicolumn{4}{|l|}{ Université de la Méditerranée, Marseille, France } \\
\hline Hôtel-Dieu Hospital, Paris, France & Morocco & Microscopic & (34) \\
\hline Hôpital de Mantes in Mantes-la-Jolie, France & Mali & Molecular tests & \\
\hline Avicenne Hospital in Bobigny, France & Mauritania & & \\
\hline $\begin{array}{l}\text { Service de maladies infectieuses et réanimation médicale, } \mathrm{CHU} \\
\text { Pontchaillou, Rennes, France }\end{array}$ & Senegal & $\begin{array}{l}\text { Microscopic } \\
\text { Molecular tests }\end{array}$ & $(40)$ \\
\hline $\begin{array}{l}\text { Infectious Diseases and Tropical Medicine ward in North Hospital, } \\
\text { Marseille, France }\end{array}$ & Ethiopia & $\begin{array}{l}\text { Molecular tests } \\
\text { Immunofluorescence assay } \\
\text { Lyme disease serodiagnostic assays (ELISA) }\end{array}$ & $(41)$ \\
\hline
\end{tabular}

studies have identified this species in patients with unexplained fever in north-western Morocco (32). However, local transmission has not been detected in Morocco since 1976 (33), with the exception of one traveler returning from Spain and Morocco with a B. hispanica infection (34). Although not present in Europe or near its boundaries, other relapsing fever borreliae species are of interest to European physicians because of the increase in international travel and cases of European tourists importing relapsing fevers. $B$. crocidurae has been detected in travelers returning from Senegal $(35,36)$ and Mali $(37)$, and other relapsing fever borreliae have been detected in travelers returning to Europe from Africa over the past 15 years (Table 1). Relapsing fever borreliae are therefore considered as emerging diseases and should consequently be considered in all febrile patients returning from endemic countries.

\section{Techniques for Epidemiological Study}

Molecular typing is used for species identification of Borrelia in epidemiological studies $(13,14,28)$. In Ethiopia, molecular investigation of 284 cattle ticks found a potential new Borrelia species distinct from both the relapsing fever group and Lyme borreliae (8). In Ethiopia, B. recurrentis DNA has also been found in $23 \%$ of head lice from patients with louse-borne relapsing fever (42).

\section{Xenodiagnosis}

Because relapsing fever borreliae are vector-borne pathogens, it is possible to use xenodiagnosis to detect the causative Borrelia in the vector. We recently developed a protocol for the rapid detection of B. crocidurae in Ornithodoros soft ticks using matrixassisted laser desorption/ionization time-of-flight mass spectrometry (MALDI-TOF-MS) (43). MALDI-TOF-MS is, thus, emerging as a potential tool for the rapid identification of vectors (44) and spirochaeta such as Leptospira (45) and Borrelia (46). We first extended it to the dual identification of vectors and vectorized relapsing fever borreliae directly in ticks (43). For each Borrelia species, a consensus pattern referred to as the mean spectrum projection (MSP) was obtained using the Biotyper MSP Creation Standard Method (Bruker Daltonics). A Borrelia MALDI-TOFMS database was created for relapsing fever borreliae and yielded a unique protein profile for each species.

After the database had been developed, MALDI-TOF-MS was able to be used to identify tick species and the presence of relapsing fever borreliae in a single assay. The Borreliae database, along with a custom software program that subtracts the uninfected Ornithodoros sonrai profile, was used to detect $B$. crocidurae. The legs were homogenized and the supernatant was spotted onto a steel target plate in quadruplicate. Using in-house subtraction software, the MSP pattern of non-infected O. sonrai was removed from the pattern of infected ticks. This software normalizes the spectra and compares common peaks in infected and uninfected ticks, subsequently generating the MSP spectra before performing the subtraction. After subtraction, the list of remaining differential masses $(m / z)$ was compared with the B. crocidurae MSP.

\section{Isolation and Culture}

Screening tests currently consist of microscopic examination and culture of midgut tissues dissected from live vectors of relapsing fever borreliae (18). Although somewhat difficult and time-consuming, this culture is definitive for the diagnosis of spirochaetal infections in ticks. It also provides a source of new Borrelia strains (47). Borreliae grow at $32^{\circ} \mathrm{C}$ in BarbourStoenner-Kelly-H (BSK-H) medium supplemented with $10 \%$ heat-inactivated rabbit serum. Dark-field microscopic observation ensures the absence of any contaminant organisms and gages 
the growth of the borreliae. Fresh blood samples from infected patients can be cultured using BSK-H medium or by intraperitoneal inoculation of 6- to 8-week-old female laboratory BALB/c mice. Borreliae in mice are detected after 5-6 days by microscopic examination of Giemsa-stained peripheral blood smears, followed by qPCR of blood samples. Outside of Africa, it has been demonstrated that Borrelia hermsii (new world relapsing fever borreliae) infection in mice can be quantified by qPCR and that this technique matched the results obtained by microscopic examination of blood smears (48). In a study based on 100 fieldcollected Ixodes ricinus ticks, dark-field microscopy, culture, and PCR were shown to be comparable as procedures for detecting Lyme borreliosis spirochaeta in ticks. Thirteen ticks were found to be positive through culture in BSK-H medium, 16 ticks were found to be infected with spirochetes by dark-field microscopy, and 22 ticks were found to contain Borrelia burgdorferi-specific DNA by PCR using a primer set based on sequences of the flagellin gene of B. burgdorferi (20). This study showed the inability of culture to detect spirochaeta compared to dark-field microscopic analysis and PCR. For the culture of tick-borne relapsing fever borreliae in Africa, B. hispanica remained uncultured in axenic medium until 1976 (49) and B. duttonii until 1999 (50). B. crocidurae, first described in musk shrew blood in Senegal in 1917 (51), was only cultured in axenic medium in 1999 (52).

\section{Serology}

No reliable specific serology exists for $B$. crocidurae infection. Indeed, the detection of $B$. burgdorferi and $B$. recurrentis by IgM enzyme-linked immunosorbent assay (ELISA) was used as a surrogate for $B$. crocidurae serology since it is thought that an appreciable cross-reacting antigen homology exists between these species and B. crocidurae (35). The $g l p Q$ gene has been proposed as a more specific recombinant antigen for serology, distinguishing relapsing fever borreliae from Lyme disease, but this test is not species-specific, it cannot date the infection and is not commercially available (25). It also failed to detect IgG response during early infection in some patients infected with $B$. recurrentis (25, 53). Serology is of little use for diagnosis as specific antibodies

\section{REFERENCES}

1. Cutler S, Abdissa A, Trape J. New concepts for the old challenge of African relapsing fever borreliosis. Clin Microbiol Infect (2009) 15:400-6. doi:10.1111/j. 1469-0691.2009.02819.x

2. Haitham E, Raoult D, Drancourt M. Relapsing fever borreliae in Africa. Am J Trop Med Hyg (2013) 89:288-92. doi:10.4269/ajtmh.12-0691

3. Trape J-F, Diatta G, Arnathau C, Bitam I, Sarih M, Belghyti D, et al. The epidemiology and geographic distribution of relapsing fever borreliosis in west and North Africa, with a review of the Ornithodoros erraticus Complex (Acari: Ixodida). PLoS One (2013) 8:e78473. doi:10.1371/journal. pone. 0078473

4. Fotso Fotso A, Angelakis E, Mouffok N, Drancourt M, Raoult D. Blood-borne Candidatus Borrelia algerica in a patient with prolonged fever in Oran, Algeria. Am J Trop Med Hyg (2015) 93(5):1070-3. doi:10.4269/ajtmh.15-0124

5. Mitani H, Talbert A, Fukunaga M. New world relapsing fever Borrelia found in Ornithodoros porcinus ticks in central Tanzania. Microbiol Immunol (2004) 48:501-5. doi:10.1111/j.1348-0421.2004.tb03545.x

6. Yabsley MJ, Parsons NJ, Horne EC, Shock BC, Purdee M. Novel relapsing fever Borrelia detected in African penguins (Spheniscus demersus) admitted to two rehabilitation centers in South Africa. Parasitol Res (2012) 110:1125-30. doi:10.1007/s00436-011-2602-2 are detectable only after the first week of infection (53). Moreover, the majority of antibodies are directed toward variable membrane proteins (Vmps), subdivided into variable small proteins (Vsps) of $20 \mathrm{kDa}$ and variable large proteins (Vlps) of $37 \mathrm{kDa}$ in the genus Borrelia (54). One disadvantage of serology in endemic areas is antibodies that remain from earlier cleared infections may result in false-positive results (53). Moreover, several relapsing fever proteins are cross-reactive to Treponema spirochaeta and Lyme group borreliae (25). No antibody has been specifically developed for the diagnosis of African relapsing fever borreliae. Recently, we produced monoclonal antibodies (MAbs) against $B$. crocidurae and characterized two of them with a higher titer in order to develop cheap assays for the rapid detection of relapsing fever borreliae (19). By combining both MAbs into immunofluorescence assays, relapsing fever Borrelia and specifically B. crocidurae were detected in ticks and blood. These antibodies could be incorporated into a dot-blot, a cheap and stable format which is well-suited to the rapid diagnosis of relapsing fevers at the POC (15).

\section{CONCLUSION}

Relapsing fevers are common diseases in local and traveling populations exposed to endemic countries in Africa. Nevertheless, they remain largely undiagnosed due to a lack of routine laboratory tests and clinical awareness. These fevers can be easily detected at POC using home-made, specific real-time PCR assays $(15,27)$. Fine identification can be then confirmed in a reference laboratory. Relapsing borrelioses should be incorporated to all tropical fever syndromic laboratory kits and an ethylenediaminetetraacetic acid (EDTA) blood tube, along with any ectoparasites that have been removed, should be collected for diagnosis purposes.

\section{ACKNOWLEDGMENTS}

This work was supported by Unité de Recherche sur les Maladies Infectieuses et Tropicales Emergentes, Marseille, France. AF receives a grant from Infectiopôle Sud, France.

7. Reye AL, Arinola OG, Hübschen JM, Muller CP. Pathogen prevalence in ticks collected from the vegetation and livestock in Nigeria Appl. Environ Microbiol (2012) 78:2562-8. doi:10.1128/AEM.06686-11

8. Mediannikov O, Abdissa A, Socolovschi C, Diatta G, Trape JF, Raoult D. Detection of a new Borrelia species in ticks taken from cattle in Southwest Ethiopia. Vector Borne Zoonotic Dis (2012) 13:266-9. doi:10.1089/vbz.2011.0874

9. Vial L, Diatta G, Tall A, Ba el H, Bouganali H, Durand P. Incidence of tick-borne relapsing fever in West Africa: longitudinal study. Lancet (2006) 368(9529):37-43. doi:10.1016/S0140-6736(06)68968-X

10. Fukunaga M, Ushijima Y, Aoki LY, Talbert A. Detection of Borrelia duttonii, a tick-borne relapsing fever agent in central Tanzania, within ticks by flagellin gene-based nested polymerase chain reaction. Vector Borne Zoonotic Dis (2001) 1:331-8. doi:10.1089/15303660160025949

11. Nordstrand A, Bunikis I, Larsson C, Tsogbe K, Schwan T, Nilsson M, et al. Tickborne relapsing fever diagnosis obscured by malaria, Togo. Emerg Infect Dis (2007) 13:117-23. doi:10.3201/eid1301.060670

12. Mediannikov O, Socolovschi C, Bassene H, Diatta G, Ratmanov P, Fenollar F, et al. Borrelia crocidurae infection in acutely febrile patients, Senegal. Emerg Infect Dis (2014) 20:1335-8. doi:10.3201/eid2008.130550

13. Haitham E, Gimenez G, Sokhna C, Bilcha K, Ali J, Barker SC, et al. Multispacer sequence typing relapsing fever Borreliae in Africa. PLoS Negl Trop Dis (2012) 6:e1652. doi:10.1371/journal.pntd.0001652 
14. Schwan TG, Anderson JM, Lopez JE, Fischer RJ, Raffel SJ, McCoy BN, et al. Endemic foci of the tick-borne relapsing fever spirochete Borrelia crocidurae in Mali, West Africa, and the potential for human infection. PLoS Negl Trop Dis (2012) 6:e1924. doi:10.1371/journal.pntd.0001924

15. Sokhna C, Mediannikov O, Fenollar F, Bassene H, Diatta G, Tall A, et al. Pointof-care laboratory of pathogen diagnosis in Rural Senegal. PLoS Negl Trop Dis (2013) 7:e1999. doi:10.1371/journal.pntd.0001999

16. Trape JF, Duplantier JM, Bouganali H, Godeluck B, Legros F, Cornet JP, et al. Tick-borne borreliosis in West Africa. Lancet (1991) 337:473-5. doi:10.1016/ 0140-6736(91)93404-W

17. Blevins SM, Greenfield RA, Bronze MS. Blood smear analysis in babesiosis, ehrlichiosis, relapsing fever, malaria, and Chagas disease. Cleve Clin J Med (2008) 5:521-30. doi:10.3949/ccjm.75.7.521

18. Gustafson R, Gardulf A, Svenungsson B. Comparison of culture, indirect immunofluorescence and dark-field microscopy for detection of spirochetes from Ixodes ricinus ticks. Eur J Clin Microbiol Infect Dis (1989) 8:570-2. doi: 10.1007/BF01967487

19. Fotso Fotso A, Mediannikov O, Raoult D, Drancourt M. Monoclonal antibodies for the diagnosis of Borrelia crocidurae. Am J Trop Med Hyg (2015) (in press).

20. Wittenbrink M, Thiele D, Krauss H. Comparison of dark-field microscopy, culture, and Polymerase Chain Reaction (PCR) for detection of Borrelia burgdorferi in field-collected Ixodes ricinus Ticks. Zbl Bakt (1994) 281:183-91. doi:10.1016/ S0934-8840(11)80568-2

21. Larsson C, Bergström S. A novel and simple method for laboratory diagnosis of relapsing fever borreliosis. Open Microbiol J (2008) 2:10-2. doi:10.2174/ 1874285800802010010

22. Toledo A, Anda P, Escudero R, Larsson C, Bergstrom S, Benach JL. Phylogenetic analysis of a virulent Borrelia species isolated from patients with relapsing fever. J Clin Microbiol (2010) 48:2484-9. doi:10.1128/JCM.00541-10

23. Lescot M, Audic S, Robert C, Nguyen T, Blanc G, Cutler SJ, et al. The genome of Borrelia recurrentis, the agent of deadly louse-borne relapsing fever, is a degraded subset of tick-borne Borrelia duttonii. PLoS Genet (2008) 4:e1000185. doi:10.1371/journal.pgen.1000185

24. Fotso Fotso A, Mediannikov O, Padmanabhan R, Robert C, Fournier PE, Raoult $\mathrm{D}$, et al. Genome sequence of Borrelia crocidurae strain 03-02, a clinical isolate from Senegal. Genome Announc (2014) 2:e1150-1114. doi:10.1128/genomeA. 01150- 14

25. Schwan TG, Schrumpf ME, Hinnebusch BJ, Anderson DE, Konkel ME. GlpQ: an antigen for serological discrimination between relapsing fever and Lyme borreliosis. J Clin Microbiol (1996) 34:2483-92.

26. Jiang J, Temenak JJ, Richards AL. Real-time PCR duplex assay for Rickettsia prowazekii and Borrelia recurrentis. Ann N Y Acad Sci (2003) 990:302-10. doi:10.1111/j.1749-6632.2003.tb07380.x

27. Babonneau J, Bernard C, Marion E, Chauty A, Kempf M, Robert R, et al. Development of a dry-reagent-based qPCR to facilitate the diagnosis of Mycobacterium ulcerans infection in endemic countries. PLoS Negl Trop Dis (2015) 9:e0003606. doi:10.1371/journal.pntd.0003606

28. Scott JC. Typing African relapsing fever spirochetes. Emerg Infect Dis (2005) 11:1722-9. doi:10.3201/eid1111.050483

29. Elbir H, Gimenez G, Robert C, Bergström S, Cutler S, Raoult D. Complete genome sequence of Borrelia crocidurae. J Bacteriol (2012) 194:3723-4. doi:10. 1128/JB.00118-12

30. Elbir H, Larsson P, Upreti M, Normark J, Bergström S. Genome sequence of the relapsing fever borreliosis species Borrelia hispanica. Genome Announc (2014) 2:e1171-1113. doi:10.1128/genomeA.01171-13

31. Anda P, Sánchez-Yebra W, del Mar Vitutia M, Pérez Pastrana E, Rodríguez I, Miller NS. A new Borrelia species isolated from patients with relapsing fever in Spain. Lancet (1996) 348:162-5. doi:10.1016/S0140-6736(96)02332-X

32. Sarih M, Garnier M, Boudebouch N, Bouattour A, Rihani A, Hassar M, et al. Borrelia hispanica relapsing fever, Morocco. Emerg Infect Dis (2009) 15:1626-9. doi:10.3201/eid1510.090403

33. Rodhain F. Borrelia et fièvres récurrentes: aspects épidémiologiques actuels. Bull Inst Pasteur (1976) 74:173-218.

34. Wyplosz B, Mihaila-Amrouche L, Baixench MT, Bigel ML, Berardi-Grassias L, Fontaine $\mathrm{C}$, et al. Imported tickborne relapsing fever, France. Emerg Infect Dis (2005) 11:1801-3. doi:10.3201/eid1111.050616

35. Million M, Cazorla C, Doudier B, La Scola B, Parola P, Drancourt M, et al. Molecular identification of Borrelia crocidurae in a patient returning from Senegal. BMJ Case Rep (2009) 2009:ii:bcr06.2008.0298. doi:10.1136/bcr.06.2008. 0298
36. Tordini G, Giaccherini R, Corbisiero R, Zanelli G. Relapsing fever in a traveller from Senegal: determination of Borrelia species using molecular methods. Trans R Soc Trop Med Hyg (2006) 100:992-4. doi:10.1016/j.trstmh.2005.11.002

37. Poirier P, Lebuisson A, Menager C, Moulin F, Dupouy-Camet J. Fever in a 7-year-old girl returning from Mali. Clin Infect Dis (2008) 47(1442):1490-1. doi:10.1086/593096

38. Goutier S, Ferquel E, Pinel C, Bosseray A, Hoen B, Couetdic G, et al. Borrelia crocidurae meningoencephalitis, West Africa. Emerg Infect Dis (2013) 19:301-4. doi:10.3201/eid1902.121325

39. Bottieau E, Verbruggen E, Aubry C, Socolovschi C, Vlieghe E. Meningoencephalitis complicating relapsing fever in traveler returning from Senegal. Emerg Infect Dis (2012) 18:697-8. doi:10.3201/eid1804.111771

40. Patrat-Delon S, Drogoul A, Le Ho H, Biziraguzenyuka J, Rabier V, Arvieux C. Recurrent tick-borne fever: a possible diagnosis in patients returning from Senegal. Med Mal Infect (2008) 38:396-9. doi:10.1016/j.medmal.2008.03.005

41. Socolovschi C, Honnorat E, Consigny PH, Dougados J, Passeron A, Parola P, et al. Tick-borne relapsing fever with cutaneous eschar and radiculopathy, Ethiopia. J Travel Med (2012) 19:261-3. doi:10.1111/j.17088305.2012.00625.x

42. Boutellis A, Mediannikov O, Bilcha KD, Ali J, Campelo D, Barker SC, et al. Borrelia recurrentis in head lice, Ethiopia. Emerg Infect Dis (2013) 19:796-8. doi:10.3201/eid1905.121480

43. Fotso Fotso A, Mediannikov O, Diatta G, Almeras L, Flaudrops C, Parola P, et al. MALDI-TOF mass spectrometry detection of pathogens in vectors: the Borrelia crocidurae/Ornithodoros sonrai paradigm. PLoS Negl Trop Dis (2014) 8:e2984. doi:10.1371/journal.pntd.0002984

44. Yssouf A, Flaudrops C, Drali R, Kernif T, Socolovschi C, Berenger JM, et al. Matrix-assisted laser desorption ionization-time of flight mass spectrometry for rapid identification of tick vectors. J Clin Microbiol (2013) 51:522-8. doi:10. 1128/JCM.02665-12

45. Djelouadji Z, Roux V, Raoult D, Kodjo A, Drancourt M. Rapid MALDI-TOF mass spectrometry identification of Leptospira organisms. Vet Microbiol (2012) 158:142-6. doi:10.1016/j.vetmic.2012.01.028

46. Calderaro A, Gorrini C, Piccolo G, Montecchini S, Buttrini M, Rossi S, et al. Identification of Borrelia species after creation of an in-house MALDI-TOF MS database. PLoS One (2014) 9:e88895. doi:10.1371/journal.pone.0088895

47. Barbour A. Isolation and cultivation of Lyme disease spirochetes. Yale J Biol Med (1984) 57:521-5.

48. McCoy B, Raffel S, Lopez J, Schwan T. Bloodmeal size and spirochete acquisition of Ornithodoros hermsii (Acari: Argasidae) during feeding. J Med Entomol (2010) 47:1164-72. doi:10.1603/ME10175

49. Kelly RT. Borrelia. In: Krieg NR, Hott JG, editors. Bergey's Manual of Systematic Bacteriology. Baltimore, MD: The Williams \& Wilkins Co (1984). p. 57-62.

50. Cutler SJ, Akintunde CO, Moss J, Fukunaga M, Kurtenbach K, Talbert A, et al. Successful in vitro cultivation of Borrelia duttonii and its comparison with Borrelia recurrentis. Int J Syst Bacteriol (1999) 49:1793-9. doi:10.1099/ 00207713-49-4-1793

51. Leger A. Spirochaete de la musaraigne (Crocidura stampfli Tentink). Bull Soc Pathol Exot (1917) 10:280-1.

52. Van Dam AP, Van Gool T, Wetsteyn JC, Dankert J. Tick-borne relapsing fever imported from West Africa: diagnosis by quantitative buffy coat analysis and in vitro culture of Borrelia crocidurae. J Clin Microbiol (1999) 37:2027-30.

53. Porcella S, Raffel S, Schrumpf M, Schriefer M, Dennis D, Schwan T. Serodiagnosis of Louse-Borne relapsing fever with glycerophosphodiester phosphodiesterase (GlpQ) from Borrelia recurrentis. J Clin Microbiol (2000) 38:3561-71.

54. Marcsisin RA, Campeau SA, Lopez JE, Barbour AG. Alp, an arthropodassociated outer membrane protein of Borrelia species that cause relapsing fever. Infect Immun (2012) 80:1881-90. doi:10.1128/IAI.06419-11

Conflict of Interest Statement: The antibodies reported herein have been patented under $N^{\circ}$ FR 2015/1461399 by Aurélien Fotso Fotso, Didier Raoult, and Michel Drancourt.

Copyright (c) 2015 Fotso Fotso and Drancourt. This is an open-access article distributed under the terms of the Creative Commons Attribution License (CC BY). The use, distribution or reproduction in other forums is permitted, provided the original author(s) or licensor are credited and that the original publication in this journal is cited, in accordance with accepted academic practice. No use, distribution or reproduction is permitted which does not comply with these terms. 